DOI https://doi.org/10.30525/978-9934-26-073-5-2-41

\title{
ОПОВІДНА СПЕЦИФІКА РЕПРЕЗЕНТАЦІЇ ТЕМИ ЕКОНОМІЧНОГО СЬОГОДЕННЯ В НІМЕЦЬКИХ МЕДІА (НА МАТЕРІАЛІ АНАЛІТИЧНОГО ОГЛЯДУ ТЕЛЕРАДІОКОМПАНІЇ «DEUTSCНЕ WELLE»)
}

\begin{abstract}
Кохан Р. А.
доцент кафедри іноземних мов для природничих факультетів Львівського національного університету імені Івана Франка м. Львів, Украӥна
\end{abstract}

Виклики та інформаційне різноманіття, якими сповнений сьогоденний медійний простір, своєрідно форматують глобальну та національні медіасистеми, ставлячи їх перед питаннями, суперечностями та значною відповідальністю. Індикатором і водночас відображенням динаміки економічної картини кожної окремої держави є засоби масової інформації, що аналізують певні події та моделюють їхній когнітивний відбиток.

Цікавими для аналізу видаються лінгвістичні варіанти/моделі, використання яких під час репрезентації актуальних подій та новин у сфері економіки відіграє ключову роль у створенні цілісного комунікативно завершеного повідомлення. Достатній та надзвичайно різноманітний матеріал для такого дослідження представлений,на нашу думку, в інтернет-ресурсі німецької державної телерадіокомпанії «Deutsche Welle».

Зауважимо, що як національне, так і глобальне медіасередовище, перебуває під впливом універсальних чинників, що визначають громадську свідомість, яка, своєю чергою, є головним чинником та ціллю діяльності медіа. Йдеться, насамперед, про географічне розташування держави, характерні ознаки функціонування іiі політичної системи, зокрема, на певному хронологічному зрізі, а також рівень освіченості громадян, рівень їхнього добробуту, культурні та ментальні особливості тощо [2]. Незаперечним атрибутом функціонування медіаринку кожної країни $є$ ступінь його строкатості. Беручи до уваги Німеччину, слід наголосити на насиченому численними пропозиціями медіапросторі.

Теоретики і практики у сфері соціальних комунікацій збагатили й розширили дослідницький дискурс розвідками, присвяченими схемам розбудови медіаринку Німеччини (П. Бухенау, Р. Девентер, Й. Гокеп, Б. Гольцнагель, Й. Діммік, Р. Зайферт, Ф. Лобігс, Г. Рьопер, С. Фляйшер, 158 
Д. Фюртбауер, Б. Хатчінс, Б. Шнайдер, М. Штайнер, М. Шток, І. Білоус, О. Білоус, В. Буренко, О. Демченко, В. Мальцева та ін.), а фахівці у галузі мовознавства приділяють увагу лексично-стилістичним маркерам організації новинно-розважального наративу (Д. Буссе, Ф. Геррманн, К. Кріппендорф, Е. Оксаар, К. Швегерль, Л. Кардаш, Ю. Кійко, Л. Компанцева, А. Кондрико, Л. Овсієнко, О. Черниш). Стрімкий обіг повідомленнєвого контенту відкриває, зокрема, перед дослідниками у галузі філології широкі перспективи для аналітичної роботи.

Спосіб подачі інформації сучасними медійними платформами поєднує усталені традиції конструювання оповідних стратегій та демонструє різноманітні експерименти при трансформаціях реальних подій для подальшого їхнього імплементування у медійну реальність. Роздумуючи над закономірностями організації оповідного тексту, О. Кучерова наголошує на дотриманні двох ключових принципів фактичності та результативності [4]. Застановившись на аналізі економічних повідомленнях в новинній стрічці ресурсу «Deutsche Welle», розглянемо способи втілення оповідних намірів на прикладі актуальної статті - «Deutschland zwischen Depression und Aufbruch» ${ }^{1}[8]-$ присвяченої поточному стану економіки Німеччини в умовах пандемії.

Квітнева стаття зосереджена, зокрема, на формуванні критичного горизонту масових споживацьких очікувань. Автори демонструють дотримання традиційних правил оповідної побудови статті та подекуди вдаються до лінгвістичних механізмів зацікавлення й «пробудження уваги» читача. Протиставлення у заголовку статті понять «Depression» та «Aufbruch» програмує як на рівні тексту, так і метатексту інтенцію пошуку правильного з двох. Вступне речення статті окреслює запитальну площину, уточнюючи заявлену в заголовку дихотомію і водночас звужуючи тематичне коло, знову-таки, апелюючи до читача: «Optimismus global, Trübsal lokal: Auf diesen Nenner lässt sich die Lage der Weltwirtschaft und die Unzufriedenheit der Bevölkerung in Deutschland mit dem Krisen- und Impfmanagement von Bund und Ländern bringen. $\mathrm{Zu}$ Recht?». Структура статті, вочевидь, впливає на якісний рівень іiі сприймання. Відтак, поділ тексту на смислові абзаци із підзаголовками до кожного не лише спрощують його рецепцію, але й постають своєрідним індикатором наближення реципієнта до семантичної площини інформаційно-аналітичного повідомлення: підзаголовки «Corona-Politik: Wie zufrieden sind die Deutschen?», «Nachzügler Deutschland», «Gedrückte Stimmung durch lange Pandemie», «Scharfe Kritik von Wirtschaft und

${ }^{1}$ «Німеччина між депресією та проривом» 
Ökonomen», «Konjunktur für Besserwisser?» логічно маркують текст для поетапного ознайомлення та семантичного заглиблення. Послідовний доцентровий аналіз сучасного стану німецької економіки - від огляду глобальних світових тенденцій до окреслення вузькодержавних реалій досягає, на наш погляд, високого ступеня інформативності завдяки використанню метафор та епітетів, що частково адаптують фактичні дані для сприймання читача.

Підрозділ статті «Lage besser als Stimmung» вже своїм формулюванням визначає позитивний вектор когнітивного процесу вже від сприймання попередньо окресленої перспективи. Вважаємо за доцільне наголосити на принциповій ролі мовних структур в закодуванні смислів для подальшої рецепції. Відтак, означимо в тексті статті два лексичносемантичних кола: судження 3 позитивною критичною оцінкою економічної ситуації в державі та негативно марковані судження. 3 огляду на загальну специфіку пандемічної економіки в світовому зрізі очікуваними є формулювання, на кшталт: «deutlich optimistischer», «voller Optimismus», «die schnellen Fortschritten», «großes Vertrauen ins Krisenmanagement der politischen Führung» чи «robuste Bauwirtschaft». Позитивна оцінка розвитку господарства так чи інакше корелює із очікуваннями та аналітичним передбаченнями фахівців цієї галузі.

Лексичне ж поле статті, що виражає негативно-критичну оцінку економічної ситуації центрується, насамперед, довкола терміну «Lockdown» в різноманітних варіаціях. Використання при цьому не німецького відповідника «Massenquarantäne», а, власне, інтернаціоналізму, вживання якого набуло глобальних масштабів, вказує на авторський намір увести статтю в семантично актуальну новинну категорію «Pandemiepolitik». Читаємо про «gedrückte Stimmung» та «die um sich greifende Frustration», що маркує сьогодення ринку. Спроби дійти до витоків кризових моментів та відшукати способи їх вирішення на мовно-організаційному рівні зводяться до використання лексем: «... zeigt die scharfe Kritik aus der Wirtschaft, dass Nervosität und Aggressivität zunehmen», «eine Stimmung der kollektiven Selbstüberschätzung», «Beim Testen und der Nachverfolgung von Kontakten müsse Deutschland einen Zahn zulegen», «In den Verträgen ... stehen Dinge, da kommen jedem Manager die Tränen», «Wir dürfen dann aber nicht mehr so zimperlich mit den Testverweigerern umgehen»

Запропонований для розгляду текст статті, як бачимо, відповідає принципам мовної та семантичної організації описового тексту: репрезентує певну статичність, підсумовує процес економічного розвитку станом на конкретний етап, а також представляє аналітичний огляд проанонсованої у заголовку проблеми. Семантичне структурування тексту статті - у першому реченні статті сформульовано результат 
аналізу представленого далі - призначене для імпліцитного зосередження уваги читача, спонукуючи його задати питання «А чому?», i відразу зосередитися на подальшому тексті, що наведеними фактами та аналітичним оглядом запропонує читачеві одну чи декілька відповідей на його запитання. Окрім того, заключна частина статті, що декларує позитивні посили для державної економіки та наголошує на реальних способах досягнення очікуваних успіхів, рецептивно обрамлює смисловий простір тексту, визначаючи його позитивні координати.

Зауважимо, що «медіалогіка» є принципово визначальною у процесі форматування і наповнення контентного простору. Йдеться, насамперед, про «селективний» підхід до організації процесу подання інформації: аналіз споживацького сприймання безпосередньо визначає подальший вектор (у більш вузькому значенні - сюжет) медійної пропозиції [7]. Тематика та спосіб іï подачі постають індикатором наближеності тексту до читача, а, відтак, конкурентоздатності сучасних медіа.

\section{Література:}

1. Білоус І. Л. Особливості розподілу публікацій різних жанрів у німецькій пресі. Науковий вісник міжнародного гуманітарного університету. Серія «Філологія». 2014. № 12. С. 196-199.

2. Бондаренко Ю. С. Альтернативна преса сучасної Німеччини (особливості функціонування, редакційна політика, місце в національній системі медіа). дис. ... канд. із соц. комунікацій: 27.00.04. Суми, 2017. 207 с

3. Демченко О. Берлинские уроки. Как устроен рынок СМИ в Германии. URL: https://lb.ua/blog/aleksandr_demchenko/353383_berlinskie_ uroki_ustroen_rinok.html

4. Кучерова О. О. Оповідна структура новинного дискурсу: основні характеристики та принципи побудови (на матеріалі британських загальнонаціональних щоденних газетних новин). Наук. зап. НаУКМА. Сер. Філол. науки. 2008. Т. 85. С. 75-77.

5. Мальцева В. В. Економічна проблематика на сторінках преси ФРН (1996-2001 рр.): дис. ... канд. філол. наук: спец. 187 10.01.08 «Журналистика». Київ, 2004. 162 с.

6. Попова А. Немецкие медиа-концерны: остаться в живых. URL: http://www.germania-online.diplo.de/Vertretung/russland-dz/ru/02wirtschaft/unternehmen/nemeckie-media-koncerny-ostatsja-v-zhivykh.html.

7. Altheide D. Media Logic. L.: Proufledge, 1979. 296 p.

8. Deutschland zwischen Depression und Aufbruch. Deutsche Welle (02.04.2021). URL: https://www.dw.com/de/deutschland-zwischendepression-und-aufbruch/a-57056235 